\title{
Commentary: Pouring life into dead tissues: A brief history of the porcine small intestine submucosa (SIS) in cardiovascular surgery—success, failures, hype, and hope
}

\author{
Kanika Kalra, MD, ${ }^{\mathrm{a}}$ and Muralidhar Padala, $\mathrm{PhD}^{\mathrm{a}, \mathrm{b}}$
}

\footnotetext{
From the aDivision of Cardiothoracic Surgery, Joseph P. Whitehead Department of Surgery, Emory University and ${ }^{\mathrm{b}}$ Structural Heart Research and Innovation Laboratory, Carlyle Fraser Heart Center at Emory University Hospital Midtown, Atlanta, Ga.

Disclosures: Dr Padala is funded by grants from the National Institutes of Health (1R01HL135145, 1R01HL140325, 1R01HL133667), the American Heart Association (14SDG20380081), the Carlyle Fraser Heart Center at Emory University Hospital Midtown, and a research grant and consulting fees from Heart Repair Technologies, Inc. Opinions expressed in this manuscript are solely of the authors and are not influenced by these funding agencies. Dr Kalra has nothing to disclose with regard to commercial support.

Received for publication Oct 10, 2019; revisions received Oct 10, 2019; accepted for publication Oct 10, 2019; available ahead of print Oct 24, 2019.

Address for reprints: Muralidhar Padala, PhD, Cardiothoracic Research Laboratories, 380B Northyards Blvd, Atlanta, GA 30313 (E-mail: spadala@emory.edu).

J Thorac Cardiovasc Surg 2020;160:e217-9

$0022-5223 / \$ 36.00$

Copyright (C) 2019 by The American Association for Thoracic Surgery

https://doi.org/10.1016/j.jtcvs.2019.10.057
}

Interspecies xenotransplantation of whole organs, tissues, or fluids is part of mythologies in several older cultures, such as the Hindu deity of Ganesha, who received an elephant's head as a transplant for his own; the Assyrian deity lamassu, depicted as having a human head with the body of a bull and wings of a bird; and a description of Daedalus, who attached bird wings to his arms to fly across from the island of Crete to mainland Greece. Our forefathers' imagination in describing xenotransplantation predates its actual use for medical applications by time unknown. The first attempts at transfusing blood from animals to humans were reported in the 17 th century, followed by skin xenografting in the 19th century, whole-organ transplantation in early decades of the 20th century with the advent of techniques to perform vascular anastomoses by Alexis Carrel, and cellular transplantation proposed by Serge Voronoff in these early decades. ${ }^{1}$

Although some strategies were partially successful, a significant number of these efforts did not reach widespread clinical use due to challenges with immune reaction elicited by the recipient to the donor material. To overcome these challenges, devitalization of the tissues with processes such a deep freezing and freeze-thaw cycles were developed, decellularization of tissues with removal of most cellular components was achieved, and fixation of the tissue with tanning agents like glutaraldehyde was adopted. Among these processes, fixing tissues with glutaraldehyde and rendering them inert to the recipient's body is most widely adopted, despite significant drawbacks of such a method as described earlier. ${ }^{2}$

Decellularization of xenografts and their use as replacement scaffolds has been an area of much interest, as such

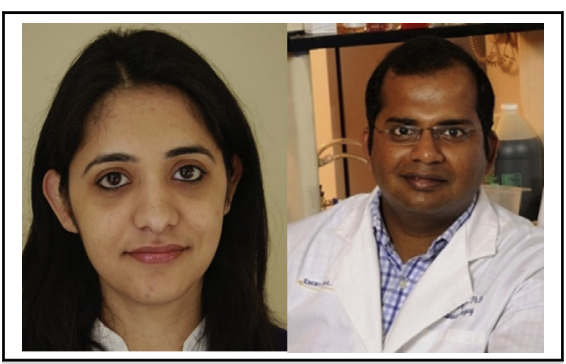

Kanika Kalra, MD (left), Muralidhar Padala, PhD (right)

Central Message

Preclinical outcomes with porcine small intestinal submucosa as cardiovascular substitutes are limited and should be translated to clinical use with caution.

See Article page e201.

tissue maintains a highly complex, 3-dimensional extracellular matrix structure with a mix of different proteins that are often challenging to replicate using human-made methods such as 3-dimensional printing and electrospinning. Devoid of donor cells, these bare extracellular matrix materials could not only provide scaffolding at the implant site but potentially recellularize with the recipient's cells for in situ tissue reconstitution. This approach has several theoretical benefits, and research activity in developing an optimized decellularized scaffold for use in different organ systems has been ongoing, as summarized elsewhere.

In the cardiovascular system, the use of decellularized materials as scaffolds was attempted by CryoLife in $1995^{3}$ when a decellularized porcine heart valve was introduced and approved for clinical use by 2001. Long-term data with these valves have been mixed in the clinical setting, with calcification, structural deterioration, and valve dysfunction occurring in patients. ${ }^{4}$ In the recent decade, decellularized porcine small intestinal submucosa (SIS) was introduced by CorMatrix as a cardiovascular scaffolding for use in both adults and children. It was marketed as a material that had a 3-dimensional architecture that is like native tissues and allows for honing of cells, it is acellular yet biologically active, eluting growth factors that sustain and proliferate honing cells, and potentially it can be absorbed and replaced by the formation of native tissue. Preclinical studies using the SIS model are several, but 
for use in the cardiovascular system, the focus should veer to studies that investigated intracardiac or vascular implantation. Six such studies exist in literature currently, ${ }^{5-10}$ of which 2 were in pigs (non-xenogenic), 1 was in calves, and 3 in sheep. As expected, the studies in pigs demonstrated better outcomes with in situ formation of fibrous tissue, neoangiogenesis, and endothelialization, whereas, the calf study demonstrated thick neointimal tissue formation and the sheep studies demonstrated host cell infiltration and trilaminar organization of the tissues. These successful studies were performed by CorMatrix, based on which clinical trials ensued.

To date, there have been several hundreds of patients who received the SIS material for intracardiac use in different forms, with a mixed outcome and a word of caution about its use in humans. The outcomes of these studies are summarized elsewhere, ${ }^{11}$ but in general structural failure of the SIS material was often observed that required reoperation. Histologic analysis of explants from some of these patients indicated thickening and chronic inflammation, without any evidence of host cell infiltration or organized in situ tissue formation. It is not surprising that humans elicit the same xenogeneic response to the porcine SIS extracellular matrix material, as seen in other species, likely attributed to remnant DNA in the processed tissue as indicated earlier.

In their report, Van Rijswijk and colleagues ${ }^{12}$ studied the efficacy of porcine SIS extracellular matrix shaped into a pulmonary valved conduit in 10 sheep and 10 lambs, with a planned survival for 6 months. In these xenogeneic studies, 5 sheep $(50 \%)$ and 8 lambs $(80 \%)$ survived the entire follow-up duration. In animals that died or were terminated prematurely, severe pulmonary stenosis with leaflet calcification and thickening were observed. At 1month follow-up, more lambs than sheep developed severe pulmonary stenosis, with extensive infiltration of inflammatory cells. Histologically, the wall of conduit had a greater density of inflammatory and alpha-smooth muscle actinpositive cells than the valve leaflets. An endothelial layer was virtually absent in all the explants. At 3 months, 2 more lambs had developed pulmonary stenosis. A smooth surface and moderate delamination were seen, with signs of calcification at the base of the leaflets and increased inflammatory cell density. Alpha-smooth muscle actinpositive cells and an endothelial layer were almost absent in all the leaflets. At 6 months, stenosis was noted in the some of the surviving lambs and severe regurgitation in some sheep. Macroscopic examination of this conduit revealed that 2 valve leaflets had completely disappeared and the remaining leaflet was thickened. The amount of cells in the leaflets did not increase over time, and there was only limited coverage by endothelial cells after 6 months. Hydroxyproline concentrations, however, were comparable with preimplant porcine small intestinal submucosa extracellular matrix (pSIS-ECM). There was no elastin fiber formation and no signs of remodeling of the implant into tissue resembling a 3-layered native heart valve. The sulfated glycosaminoglycans concentration increased over time but did not attain native valve levels. DNA concentrations were highly variable and did not significantly change over time or compared with pSISECM before implantation and were lower than in native valves. Biaxial mechanical testing demonstrated that the tangent modulus decreased at all time points as compared with pSIS-ECM before implantation. In summary, this report brings forth data that pSIS-ECM elicits a high degree of inflammatory response on xenogeneic transplantation and results in poor long-term outcomes as a pulmonary valve in sheep and lambs.

Based on the mixed preclinical data and poor clinical data, is it now time to call for a moratorium on the pSISECM matrix for use in cardiovascular applications? Simple, one-word answers to this question would be unjust, but evidence is growing against its durability and remodeling potential, and controlled studies in different species and potentially in non-human primates may be warranted. The inventive, early-adopter surgeon can argue that testing such materials in human patients is the only way forward to understand and redesign the material, but such an argument may start to fall short based on the clinical evidence that has already accumulated against this material. At this juncture, the question also transforms into an ethical one-should you choose the pSIS-ECM matrix for your patients based on hype and hope?

\section{References}

1. Roux FA, Sai P, Deschamps JY. Xenotransfusions, past and present. Xenotransplantation. 2007;14:208-16.

2. Padala M. A heart valve is no stronger than its weakest link: the need to improve durability of pericardial leaflets. J Thorac Cardiovasc Surg. 2018;156:207-8.

3. O'Brien MF. The Cryolife-O'Brien composite aortic stentless xenograft: surgical technique of implantation. Ann Thorac Surg. 1995;60:S410-3.

4. Pavoni D, Badano LP, Ius F, Mazzaro E, Frassani R, Gelsomino S, et al. Limited long-term durability of the Cryolife O'Brien stentless porcine xenograft valve. Circulation. 2007;116:I307-13.

5. Matheny RG, Hutchison ML, Dryden PE, Hiles MD, Shaar CJ. Porcine small intestine submucosa as a pulmonary valve leaflet substitute. J Heart Valve Dis. 2000;9:769-74; discussion 774-5.

6. Rosen M, Roselli EE, Faber C, Ratliff NB, Ponsky JL, Smedira NG. Small intestinal submucosa intracardiac patch: an experimental study. Surg Innov. 2005;12: 227-31.

7. Ruiz CE, Iemura M, Medie S, Varga P, Van Alstine WG, Mack S, et al. Transcatheter placement of a low-profile biodegradable pulmonary valve made of small intestinal submucosa: a long-term study in a swine model. J Thorac Cardiovasc Surg. 2005;130:477-84.

8. White JK, Agnihotri AK, Titus JS, Torchiana DF. A stentless trileaflet valve from a sheet of decellularized porcine small intestinal submucosa. Ann Thorac Surg. 2005;80:704-7.

9. Fallon AM, Goodchild TT, Cox JL, Matheny RG. In vivo remodeling potential of a novel bioprosthetic tricuspid valve in an ovine model. J Thorac Cardiovasc Surg. 2014; 148:333-40.e1.

10. Zafar F, Hinton RB, Moore RA, Baker RS, Bryant R III, Narmoneva DA, et al. Physiological growth, remodeling potential, and preserved function of a novel bioprosthetic tricuspid valve: tubular bioprosthesis made of small intestinal submucosa-derived extracellular matrix. J Am Coll Cardiol. 2015;66:877-88. 
11. Mosala Nezhad Z, Poncelet A, de Kerchove L, Gianello P, Fervaille C, El Khoury G. Small intestinal submucosa extracellular matrix (CorMatrix(R)) in cardiovascular surgery: a systematic review. Interact Cardiovasc Thorac Surg. 2016;22:839-50.
12. van Rijswijk J, Talacua $\mathrm{H}$, Mulder $\mathrm{K}$, van Hout $\mathrm{G}$, Bouten $\mathrm{C}$, Grundeman P, et al. Failure of decellularized porcine small intestinal submucosa as a heart valved conduit. J Thorac Cardiovasc Surg. 2020;160: e201-15. 